\title{
Are Video Games the Best Way to Stay-at-Home?
}

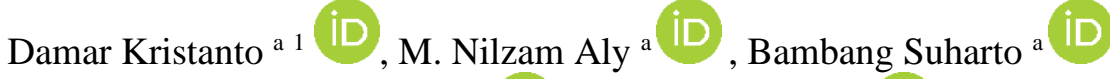 \\ Rahmat Yuliawan a Aji Akbar Firdaus a iD \\ ${ }^{a}$ Department of Business Faculty of Vocational Studies, Universitas Airlangga, Surabaya
}

\section{APA Citation:}

Kristanto, D., Aly, M.N., Suharto, B., Yuliawan, R. \& Firdaus, A.A. (2021). Are video games the best way to stay-at-home?. TIJAB (The International Journal of Applied Business), 5(1), 51-59.

Submission Date: 05/02/2021

Acceptance Date: $24 / 04 / 2021$

\begin{abstract}
The COVID-19 pandemic has disrupted many aspects of normal social life. The community is required not to leave the house too much if it is not necessary. Often during times of independent isolation or in personal cases, people are afraid to leave the house. They are faced with boredom so this is an opportunity for the digital entertainment industry to develop. On the other hand, many violations of COVID-19 health protocols still occur in society and people are still reluctant to stay-at-home. The question is what medium is good for persuasion as well as giving pleasure to people to entertain themselves during independent isolation and with low levels of boredom. Video games are a growing industry during the COVID-19 pandemic, unfortunately, this media has not been widely used as a means of persuading people to obey health protocols and stay-at-home. This study shows a correlation between gaming activity and the tendency not to leave the house. Besides, what types of games have the potential to keep someone from leaving the house are also discussed in this paper.
\end{abstract}

Keywords: COVID-19; stay-at-home; video games; health protocols; digital entertainment.

This is an open access article under the CC BY-NC-SA license.

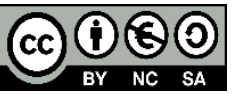

\section{Introduction}

Since March 2020, the Coronavirus (COVID-19) pandemic has an increasing number of cases and has not yet decreased in Indonesia. The COVID-19 pandemic has also disrupted many joints of normal life activities globally. We always seek to implement and enforce discipline so that members of the community always carry out health protocols such as washing hands frequently, always wearing masks, and always maintaining a distance from other people. However, the best effort to reduce transmission numbers is to stay at home. Stay-at-home is a mandate that can increase the consumption of digital entertainment (King et al. 2020). One of the digital entertainment that is experiencing an increase in business is video games (Tashanova et al. 2020) including those based on mobile. (Wanga et al. 2020).

\footnotetext{
${ }^{1}$ Corresponding author.

E-mail address: damar-kristanto@vokasi.unair.ac.id
} 
In order to fight COVID-19, nutritional intake that can increase immunity is mandatory, moreover, it turns out that increasing psychological wellness is also a must. When someone is required to just stay at home, boredom is something they must face, and to suppress this boredom they will look for ways to entertain themselves, so that the screen time for consuming digital entertainment products will also be very high (Coley et al. 2020). However, the excess consumption of digital entertainment products has actually caused new boredom due to monotonous and repetitive activities, which in the end they will burn out and leave the house to look for other variations of entertainment.

This study seeks to explain how the correlation of video game consumption duration will play an important role in efforts to refrain from video game players staying indoors, and what efforts should be made to reduce boredom when playing video games.

\section{Literature Review}

\subsection{Video Games and the Covid-19 Pandemic}

In essence, video games sell the experience of playing which is presented in a particular gameplay concept (Kristanto, 2018). When entering the pandemic season of COVID-19, surprisingly the video game industry experienced an increase in demand when mainstream entertainment industries such as tourism, cinemas, and restaurants experienced a setback. Video games may still be seen as something negative for some circles, however, in reality, the appreciation of video games during the COVID-19 pandemic is very high and provides benefits not only to creators but also video game players when they self-quarantine or isolate themselves ( Zhu, 2020). The role of video games has become very central during the COVID-19 pandemic in cases of self-quarantine or self-isolation, the form of pleasure produced is very different when compared to other forms of pleasure such as watching movies (Marston and Kowert, 2020). For example, a person would be bored if he watched a 2-hour film with 5 films in one day, the resulting activity was only as minimal as the eye while the body relaxed. This actually makes a person bored, but in the case of playing video games, it seems as if the player is just sitting facing a computer or smartphone screen, but the essence of the adrenaline rush occurs in the body's metabolism so that they often feel tensions which actually become the power to enjoy playing video games.

Based on a study conducted by Newzoo in 2020, it noted that in 2020 the number of e-sports audiences reached 495 million. In fact, the e-sports industry itself was able to record an increase of $15 \%$ compared to the previous year with total revenue of 1100.1 million dollars. This gives a signal that this industry is surviving during the COVID-19 Pandemic. Based on this, it provides an indication that video games should be a sufficiently effective medium for campaigning for compliance with health protocols.

\subsection{Video Game Genre}

In October 1958, Physicist William Higinbotham created what is thought to be the first video game. It was a very simple tennis game, similar to the classic 1970s video game Pong. Since then, the development of video games has expanded into various genres. Table 1 shows that until 2020 at least video games have been classified into 11 popular genres.

Even though the genres can be classified into 11 genres, the types of gameplay haven't changed too much. A repetitive type of gameplay means that players are required to play the game with the same mechanism over and over again. Stage Development means that players are required to be patient and wait for the time to develop a game simulation. Narrative means that players are given guidance in playing and are required to follow the storyline embedded in the video game, and Explorative is a type 
of game that provides as much freedom as possible for the player to do whatever he wants in the video game.

Table 1. Video game popular genre

\begin{tabular}{|c|c|c|c|c|}
\hline Genre & Player & Platform & Gameplay & Example \\
\hline $\begin{array}{l}\text { Arcade/ } \\
\text { Platformer }\end{array}$ & 1-2 Player & Offline/Console/PC & Repetitive & $\begin{array}{l}\text { Striker 1945, } \\
\text { Megaman X, } \\
\text { Super Mario. }\end{array}$ \\
\hline $\begin{array}{l}\text { Life Simulation/ } \\
\text { Builder }\end{array}$ & 1 Player & Offline/Console/PC & $\begin{array}{l}\text { Stage } \\
\text { Development }\end{array}$ & $\begin{array}{l}\text { The Sims, Dragon } \\
\text { Quest Builder } 2\end{array}$ \\
\hline $\begin{array}{l}\text { Multi Stage } \\
\text { Adventure }\end{array}$ & $\begin{array}{l}\text { Multi Player } \\
\text { (more than } 2 \\
\text { player) }\end{array}$ & Online/Smartphone & Repetitive & $\begin{array}{l}\text { King's Raid, } \\
\text { Honkai Impact } 3\end{array}$ \\
\hline Sport & 1-2 Player & Offline/Console/PC & Repetitive & FIFA 2020 \\
\hline Open World RPG & $\begin{array}{l}\text { Multi Player } \\
\text { (more than } 2 \\
\text { player) }\end{array}$ & Online/PC/Smartphone & Explorative & $\begin{array}{l}\text { Genshin Impact, } \\
\text { Witcher } 3\end{array}$ \\
\hline Arena & $\begin{array}{l}\text { Multi Player } \\
\text { (more than } 2 \\
\text { player) }\end{array}$ & Online/PC/Smartphone & Repetitive & $\begin{array}{l}\text { DOTA 2, Mobile } \\
\text { Legend }\end{array}$ \\
\hline Fighting & 1-2 Player & Offline/Console/PC & Repetitive & $\begin{array}{l}\text { Tekken 7, Smash } \\
\text { Bros }\end{array}$ \\
\hline RPG & 1 Player & Offline/Console/PC & Narrative & Final Fantasy XIII \\
\hline Strategy & 1 Player & Offline/PC & Repetitive & $\begin{array}{l}\text { Starcraft, } \\
\text { Nobunaga } \\
\text { Ambition }\end{array}$ \\
\hline $\begin{array}{l}\text { First Person } \\
\text { Shooter }\end{array}$ & $\begin{array}{l}\text { Multi Player } \\
\text { (more than } 2 \\
\text { player) }\end{array}$ & Online/PC/Smartphone & Repetitive & PUBG \\
\hline Tap-Tap Music & 1-2 Player & $\begin{array}{l}\text { Online/PC/ } \\
\text { Console/Smartphone }\end{array}$ & Repetitive & $\begin{array}{l}\text { Ban-G Dream, } \\
\text { Guitar Hero }\end{array}$ \\
\hline
\end{tabular}

\subsection{Flow Theory}

Flow can be defined as a psychological condition that experienced by a person when doing certain activities, in which the activity actor feels like being fully involved, united with his activity, attention is focused on the operationalization of the activity (Hsu and Lu, 2004) so that he loses awareness of spatial conditions around them (Cho and Kim, 2012) and feel complete control over the environment of their activities (Hoffman and Novak, 2009).

This condition makes it very possible for video game players to be immersed in playing activities so that players tend to be open to the stimuli provided in the game (Kristanto, 2018). Based on this theory, video game players who are immersed in the game should be more receptive to social arguments such as campaigns to adhere to health protocols and to stay at home during a pandemic. In addition, with a high flow rate, players should devote their energy so they are reluctant to leave the house. Based on this, there should be a very high correlation between increased gaming activity and a decreased tendency to leave the house.

\subsection{Boredom}

The Boredom concept can be defined as a psychological condition that shows a person's dissatisfaction because they do not do something (Boylan et al. 2021) or feel that doing pointless work, meaningless or there is no challenge (Waterschoot et al. 2021). In the COVID-19 pandemic situation, 
boredom as a result of too long self- isolation will cause excessive stress (Yan et al. 2021) and lead to behavior violating health protocol rules (Boylan et al. 2021). Entertainment that is based at home seems to be the answer to reduce stress caused by boredom in the scenario of self- isolation at home. The absence of variety of entertainment media will also lead to a new boredom because people are too often using the same entertainment media. For example, maybe a film is a good entertainment form in a selfisolation scenario, but one film title can only be enjoyed for 3 hours, even though someone watches various movie titles, but watching activities that make someone only sitting still and watching, will only cause new boredom, saturation to do watching activities. Video games have different elements, players are required to have high involvement in the game and often this refers to a feeling of excitement that makes players lose track of time, and ends up playing video games with a very long duration (Kristanto, 2018).

\section{Method}

This study uses a quantitative approach by conducting a survey of respondents. The questionnaire was given to 321 respondents. Respondents in this study are those who have sufficient knowledge in playing games both mobile via smart mobile devices and through game consoles such as Playstation, Xbox, and Nintendo. and also through a computer device (PC).

The survey results in this study indicate that the majority of respondents (64\%) open an average of 1-3 times a day of game applications or play video games. 55.4\% of respondents admitted that they spend an average of 1-3 hours playing video games at home and 33.4\% of them spend an average of 46 hours playing video games at home. The interesting thing is that $38 \%$ of respondents found that they are mostly outside the house at least 4-6 hours a day on average, and $37 \%$ of respondents admitted that an average of 7-10 hours is outside the house. The most dominant location when they are outside the house is a cafe with a frequency of $34 \%$ of the respondents. Table 2 shows the activity data of the respondents.

Table 2. Respondents' activities

\begin{tabular}{lll}
\hline Data & Frequency & Percentage $(\%)$ \\
\hline The average number of times you open the & & \\
game application in one day? & 207 & 64 \\
1-3 times & 97 & 30 \\
4-6 times & 17 & 5 \\
7-10 times & 321 & 100 \\
Total & & \\
On average, how long (hours) are you playing & & \\
games at home in one day? & 178 & 55.4 \\
1-3 hours & 107 & 33.4 \\
4-6 hours & 30 & 9.4 \\
7-10 hours & 6 & 1.8 \\
>10 hours & 321 & 100 \\
Total & & \\
On average how long (hours) do you have & & \\
outside the house in one day? & $1-3$ Jam & 19 \\
1-3 hours & $4-6$ Jam & 38 \\
4-6 hours & $7-10$ Jam & 37 \\
7-10 hours & $>10$ Jam & 6 \\
> 10 hours & Total & 100 \\
Total & & \\
Where if you're outside? & 63 & 19.62617 \\
Office & 70 & 21.80685 \\
Mall &
\end{tabular}




\begin{tabular}{lll} 
Minimarket & 20 & 6.23053 \\
Cafe & 112 & 34.89097 \\
Campus & 25 & 7.788162 \\
Others & 31 & 9.657321 \\
Total & 321 & 100 \\
\hline
\end{tabular}

The next step, we tried to see if there is a correlation between the duration of playing games and the tendency to stay indoors. First, we look at the relationship between the average number of respondents opening game applications or turning on their digital devices to play games and the average duration they play video games in one day. The result is that there is a fairly high correlation between the average number of respondents opening game applications or turning on their digital devices to play games and the average duration they play video games in one day (Pearson Correlation 0.731, Sig. 0.000).

Table 3. Correlation of opening game applications with the duration of playing time in one day.

\begin{tabular}{|c|c|c|c|c|}
\hline \multicolumn{2}{|l|}{ Correlations } & \multirow{2}{*}{\multicolumn{2}{|c|}{$\begin{array}{l}\text { How many times } \\
\text { opens the game } \\
\text { application }\end{array}$}} & \multirow[b]{2}{*}{$\begin{array}{l}\text { Average playing game at } \\
\text { home in single day }\end{array}$} \\
\hline & & & & \\
\hline How many times opens the & Pearson Correlation & 1 & & $.731^{* *}$ \\
\hline & Sig. (2-tailed) & & & .000 \\
\hline \multirow{4}{*}{$\begin{array}{l}\text { Average playing game at } \\
\text { home in single day }\end{array}$} & $\mathrm{N}$ & 321 & & 321 \\
\hline & Pearson Correlation & $.731^{* *}$ & & 1 \\
\hline & Sig. (2-tailed) & .000 & & \\
\hline & $\mathrm{N}$ & 321 & & 321 \\
\hline
\end{tabular}

**. Correlation is significant at the 0.01 level (2-tailed).

Then we tried to see if there was a close relationship between the average duration of playing video games at home and the duration outside the house. As a result, it turns out that there is a close relationship between the average duration of playing video games at home and the duration outside the house in one day (Pearson Correlation -0.684, Sig. 0.000). The correlation coefficient is negative, this means that the longer the duration of playing games in the house, the respondents tend not to be outside the house long.

Table 4. Correlation of the duration of playing games inside the house in one day with the duration outside the house.

\begin{tabular}{llll}
\hline Correlations & $\begin{array}{l}\text { Average playing } \\
\text { games at home in } \\
\text { one day }\end{array}$ & $\begin{array}{c}\text { Tespondent is outside } \\
\text { the house in one day }\end{array}$ \\
\hline $\begin{array}{l}\text { Average playing games at } \\
\text { home in one day }\end{array}$ & $\begin{array}{l}\text { Pearson Correlation } \\
\text { Sig. (2-tailed) }\end{array}$ & 1 & $-.684^{* *}$ \\
& $\mathrm{~N}$ & 321 & .000 \\
The average respondent is & Pearson Correlation \\
outside the house in one day & Sig. (2-tailed) & $-.684^{* *}$ & 321 \\
& $\mathrm{~N}$ & 321 & 1 \\
& & & 321 \\
\hline
\end{tabular}

**. Correlation is significant at the 0.01 level (2-tailed). 
If these results are combined with the frequency of the respondent's activity, it turns out that most respondents are in cafes \& coffee shops when they are outside the house. Meanwhile, we know that cafes \& coffee shops are some of the locations that are quite prone to Covid-19 transmission. Based on these results, we also made observations in several cafes in Surabaya and found that even though during the Covid-19 pandemic, cafes and coffee shops were still crowded with visitors and the tendency to violate health protocol did not appear to be taken seriously. So that through this data, we also conduct outreach activities on the importance of health protocol and also distribute masks and hand sanitizers to several cafes and coffee shops.

\section{Discussion}

In this study, it is known that there is a high correlation between the duration of playing video games and the duration outside the home. The negative correlation coefficient value indicates that the higher the duration of playing games inside the house is correlated with the lower the duration of the respondents being outside the house. Respondents' energy seems to be exhausted by WFH activities (for work or college) and the remaining time and energy is diverted into playing video games as entertainment in the house and of course rest time such as sleeping and other activities in the house. So that respondents are lazy to go out of the house. It is different when the duration of playing video games is low, it turns out that the respondents are mostly outside the house and the most locations visited by respondents are cafes and coffee shops. Cafes and coffee shops are locations that are quite prone to Covid-19 transmission.

The results of this study provide insight into what kind of game media can psychologically restrain the movement of these video game players and keep them stay at home. The data was collected from Google PLAY (without an account). Access without an account is intended to avoid bias caused by game application recommendations provided by the GPLAY system. Based on observations in the first 10 pages, there are at least 420 game applications offered.

Table 5. The number of game applications on 10 GPlay pages.

\begin{tabular}{llll}
\hline No. & \multicolumn{1}{c}{ Genre } & \multicolumn{1}{c}{ Sum } & \multicolumn{1}{c}{ Percentage (\%) } \\
\hline 1 & Arcade & 54 & 13 \\
2 & Life Simulation & 63 & 15 \\
3 & Multi Stage Advanture & 181 & 43 \\
4 & Sport & 104 & 25 \\
5 & Open World & 18 & 4 \\
& Total & 420 & 100 \\
\hline
\end{tabular}

When looking at it from a different perspective, it turns out that video games are not only treated as a medium for playing but in fact watching other people play is also a form of derivative entertainment that cannot be underestimated either. Based on records from Newzoo in 2020, it shows viewers watching game players in action via social media streaming for PUBG alone, reaching 27.9 million viewers.

Table 6. The number of esports audience according to the Newzoo 2020 survey.

\begin{tabular}{|c|c|c|c|c|}
\hline No. & Title & & Platform & Total (M) \\
\hline 1 & League of Legend & & $\mathrm{PC}$ & 348.8 \\
\hline 2 & Dota 2 & & $\mathrm{PC}$ & 198.9 \\
\hline 3 & Arena of Valor & & Mobile & 31.6 \\
\hline 4 & PUBG Mobile & & Mobile & 27.9 \\
\hline 5 & $\begin{array}{l}\text { Super Smash } \\
\text { Ultimate }\end{array}$ & Bros. & Console & 18.6 \\
\hline
\end{tabular}




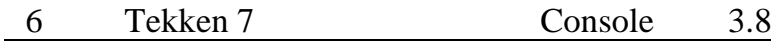

If we look at the number of game applications offered, it seems that the game in the form of multistage adventure and arcade still dominates, unfortunately, in its game operations, this type of game leads more players to repeat similar activities so that the level of player boredom is very high. This does not help players to stay playing for a long time (flow in the game). Kristanto (2018) states that the type of game that emphasizes repetitive factors will tend to be boring and players are unable to achieve long flow conditions. Understanding the flow conditions in playing this game also provides additional knowledge that in a pandemic condition that encourages someone to stay at home, it is related to the type of game that psychologically supports players to stay at home. Games that tend to be repetitive like sports, multi-stage adventure and arcade do not have a maximum effect because players will quickly get bored, while narrative and exploration-type games such as life simulation and the open-world have high potential to keep players playing longer. So theoretically if a player is playing this kind of game in the house, the player tends not to leave the house, therefore embedding this type of game in propaganda or a campaign to comply with protocols and stay indoors will be very effective, especially for video game fans (Ellis et al. 2020).

Even though video games have been divided into various genres, when looking at the gameplay, it has a similar tendency. Games that fall in the recurring gameplay category mean that in the video game the player will very often carry out the same activity continuously, for example, a sport video game such as FIFA 2020, requires players to play soccer in a game with soccer regulations, the same ball, over and over again. So that there is not much variation. On the other hand, this type of gameplay will be able to train the player's ability to become better until he becomes an expert due to the repetitive effect of learning. However, this kind of gameplay tends not to be played for a long period in one day. The repetitive gameplay will cause the player to get bored quickly because the player is becoming more skilled and it is felt that the game is no longer challenging.

Unlike the Stage development type of gameplay which requires patience and a long time, this type also gives a boring effect because the player probably doesn't want to wait too long. Narrative gameplay type may be a pretty good choice, narrative gameplay combines elements of play, development, and story, so that the player is like playing a novel or being an actor in a story, this gives players a lot of new stimuli that prevent from getting bored quickly in playing. The narrative genre has the potential to reduce the boredom of playing video games and the boredom of doing nothing in the scenario of self-isolation at home. However, the narrative genre has a limited range of embedded stories, when the story has reached the ending, the game is finished. However, this can be anticipated with a variety of similar game titles offered on the Internet. Another genre that also has the potential to reduce player boredom when independently isolated at home is a video game with the open-world adventure genre, which offers an exploration aspect of the world created in the game. The open-world game type frees players to go to any location in the video game. Even players are not required to always think about completing quests but can relax in it by enjoying the digital natural scenery, natural sounds, and background music. Open world games are a new form of e-leisure (Kristanto, 2018).

\section{Conclusions}

This study wants to see the correlation between the behavior of playing video games with the tendency of video game players to try to stay at home and see how video game applications should be a potential medium to advertise campaigns that comply with health protocols and stay indoors. This research is still inseparable from its shortcomings, the respondents used are video game players who understand how to operate video game games, but do not explain their behavior outside of them as game players because regardless of their character as video game players, respondents are also working people 
and also students. In this case, the bias might occur because the respondent might stay indoors because they are WFH or maybe leave the house because of work needs. Apart from this, this study was able to present a very close correlation data between the duration of playing video games and the tendency to no longer leave the house. To reduce boredom in playing video games when included in a self-isolation scenario at home, the open-world genre still seems to be a good choice to play.

\section{References}

Boylan, J., Seli, P., Scholer, A. A., \& Danckert, J. (2021). Boredom in the COVID-19 pandemic: Trait boredom proneness, the desire to act, and rule-breaking. Personality and Individual Differences, $171,110387$.

Colley, R. C., Bushnik, T., \& Langlois, K. (2020). Exercise and screen time during the COVID-19 pandemic. Health Rep, 31(6), 3-11.

Ellis, L. A., Lee, M. D., Ijaz, K., Smith, J., Braithwaite, J., \& Yin, K. (2020). COVID-19 as 'Game Changer'for the Physical Activity and Mental Well-Being of Augmented Reality Game Players During the Pandemic: Mixed Methods Survey Study. Journal of medical Internet research, 22(12), e25117.

King, D. L., Delfabbro, P. H., Billieux, J., \& Potenza, M. N. (2020). Problematic online gaming and the COVID-19 pandemic. Journal of Behavioral Addictions, 9(2), 184-186.

Kristanto, D. (2018). The Impact of Game Avatar Customization in Improving User Experience and Gamer Loyalty: Experiment in Role Playing Game (RPG) Based Video Game, 2(2). PP. 86-106.

Marston, H. R., \& Kowert, R. (2020). What role can videogames play in the COVID-19 pandemic?. Emerald Open Research, 2.

Newzoo. (2020). 2020 Global Esport Market Report. Newzoo.com.

Tashanova, D., Sekerbay, A., Chen, D., Luo, Y., Zhao, S., \& Zhang, T. (2020). Investment opportunities and strategies in an era of Coronavirus pandemic. Available at SSRN 3567445.

Wanga, H., Joseph, T., \& Chuma, M. B. (2020). Social Distancing: Role of Smartphone During Coronavirus (COVID-19) Pandemic Era. International Journal of Computer Science and Mobile Computing, 9(5), 181-188.

Zhu, L. (2020). The psychology behind video games during COVID-19 pandemic: A case study of Animal Crossing: New Horizons. Human Behavior and Emerging Technologies.

Waterschoot, J., Van der Kaap-Deeder, J., Morbée, S., Soenens, B., \& Vansteenkiste, M. (2021). "How to unlock myself from boredom?" The role of mindfulness and a dual awareness-and actionoriented pathway during the COVID-19 lockdown. Personality and Individual Differences, 175, 110729.

Yan, L., Gan, Y., Ding, X., Wu, J., \& Duan, H. (2021). The relationship between perceived stress and emotional distress during the COVID-19 outbreak: Effects of boredom proneness and coping style. Journal of anxiety disorders, 77, 102328.

Zhu, L. (2020). The psychology behind video games during COVID-19 pandemic: A case study of Animal Crossing: New Horizons. Human Behavior and Emerging Technologies. 
Apakah Video Game Cara Terbaik untuk Tetap di Rumah?

\begin{abstract}
Abstrak
Pandemi COVID-19 telah mengganggu banyak aspek kehidupan sosial normal. Masyarakat dituntut untuk tidak terlalu sering keluar rumah jika memang tidak perlu. Seringkali selama masa isolasi mandiri atau dalam kasus pribadi, mereka takut keluar rumah, mereka dihadapkan pada kebosanan sehingga ini adalah peluang bagi industri hiburan digital untuk berkembang. Di sisi lain, masih banyak pelanggaran COVID-19 yang terjadi di masyarakat dan masyarakat masih enggan tinggal di rumah. Pertanyaannya adalah media apa yang baik untuk persuasi sekaligus memberikan kesenangan kepada orang-orang untuk menghibur diri mereka sendiri selama isolasi independen dan dengan tingkat kebosanan yang rendah. Video game adalah industri yang berkembang selama pandemi COVID-19, sayangnya media ini belum banyak digunakan sebagai alat untuk membujuk masyarakat agar mematuhi protokol kesehatan dan tinggal di rumah. Studi ini menunjukkan adanya korelasi antara aktivitas bermain game dengan kecenderungan untuk tidak keluar rumah. Selain itu, jenis permainan apa saja yang berpotensi membuat seseorang tidak keluar rumah juga dibahas dalam tulisan ini.
\end{abstract}

Kata kunci: COVID-19; tinggal di rumah; video game; protokol Kesehatan; hiburan digital. 